\title{
Metode Pengembangan Sosial Emosional Anak Usia Dini Pada Masa Covid-19
}

\author{
Salamiyah Nur Hakim Harahap ${ }^{1}$, Mitha Nur Amalina², Khadijah ${ }^{3}$ \\ ${ }^{123}$ Universitas Islam Negeri Sumatera Utara \\ salamiyahharahap@gmail.com
}

Received: 14 Oktober 2021

Accepted: 30 November 2021

Published: 30 November 2021

\begin{abstract}
Methods for Early Childhood Social Emotional Development during the Covid-19 Period. The stages of life from birth to death are shaped by the social influences which the person interacts with. In order to develop the social aspects of children, a family role, especially the parents, is needed so that children can develop properly. Social and emotional development are inseparable from one to another. Positive social and emotional development makes it easier for children to get along with others and learn better, as well as in other activities in the social environment. This study aims to determine the strategies taken by parents to develop the socio-emotional aspects of early childhood during the Covid-19 pandemic. The results of this study are that the strategies carried out by parents include providing understanding and education about the pandemic situation, in addition to holding other activities that can be done at home including playing with the mother as practiced by the informants. From the results of interviews, the researcher takes the point that good communication between children and parents, especially by mothers, will make the children easier to understand the conditions for activities that have changed due to the current pandemic.
\end{abstract}

Keywords: emotional social, early childhood, parents.

\begin{abstract}
Abstrak. Metode Pengembangan Sosial Emosional Anak Usia Dini Pada Masa Covid-19. Tahapan kehidupan dari lahir sampai mati dibentuk oleh lingkungan sosial pengaruh yang berinteraksi dengan orang tersebut. Untuk mengembangkan aspek sosial anak, peran keluarga terutama orang tua adalah diperlukan agar anak dapat berkembang dengan baik. Sosial dan emosional pembangunan tidak dapat dipisahkan antara satu dengan yang lainnya. Sosial yang positif dan perkembangan emosi membuat anak lebih mudah bergaul orang lain dan belajar lebih baik, serta dalam kegiatan lain di masyarakat lingkungan. Penelitian ini bertujuan untuk mengetahui strategi yang dilakukan oleh orang tua untuk mengembangkan aspek sosio-emosional anak usia dini selama pandemi Covid-19. Hasil dari penelitian ini adalah bahwa strategi yang dilakukan oleh orang tua antara lain memberikan pemahaman dan edukasi tentang situasi pandemi, selain mengadakan kegiatan lain yang bisa dilakukan di rumah termasuk bermain dengan ibu seperti yang dilakukan oleh informan. Dari hasil wawancara, peneliti mengambil titik bahwa komunikasi yang baik antara anak-anak dan orang tua, terutama oleh ibu, akan membuat anak-anak lebih mudah untuk memahami kondisi kegiatan yang telah berubah karena pandemi saat ini.
\end{abstract}

Kata kunci: sosial emosional, anak usia dini, orang tua 


\section{PENDAHULUAN}

Saat ini negara Indonesia sedang mengalami musibah besar, yaitu adanya wabah atau virus yang menyerang manusia di seluruh dunia yang bernama Covid-19. Wabah tersebut bisa menyerang siapapun sehingga negara Indonesia harus waspada dan menetapkan untuk melakukan kegiatan di rumah saja, serta harus social distancing untuk memutus rantai penyebaran Covid-19 (Cahyati \& Kusumah, 2020). Sejak tanggal 11 Maret 2020 wabah tersebut ditetapkan sebagai pandemi Covid-19. Pemerintah mengeluarkan Surat Edaran Menkibud No. 4 tahun 2020 yang menetapkan aturan belajar dari rumah (learn from home) bagi anak-anak sekolah dan bekerja dari rumah (work from home). Untuk pendidikan di Indonesia, situasi seperti ini dikatakan menjadi fenomena yang tak terduga bagi seorang guru, orang tua dan anak (Iftitah \& Anawaty, 2020).

Pada masa usia dini anak mengalami masa keemasan (the golden years) yakni masa dimana anak akan mulai peka/sensitif terhadap berbagai rangsangan. Masa peka pada anak-anak biasanya berbeda-beda, seiring dengan laju pertumbuhan dan perkembangan anak secara individual. Masa peka adalah masa terjadinya kematangan fungsi fisik dan psikis yang siap merespon stimulasi yang diberikan oleh lingkungan. Dalam dua tahun pertama itu sangat penting pada kehidupan manusia bagi perkembangan anak (Mawar et.al., 2021).

American Academic of Pediartrics mengatakan bahwa perkembangan sosial emosi mengacu kepada kemampuan anak untuk memiliki pengetahuan dalam mengelola dan mengekspresikan emosi secara lengkap baik emosi positif maupun negatif, mampu menjalin hubungan dengan anak-anak dan orang dewasa. Serta aktif mengeksplorasi lingkungan melalui belajar. Menurut Nurmalitasari (2015) pada hakekatnya anak usia dini mempunyai pola pertumbuhan dan perkembangan dalam aspek fisik,kognitif,sosial emosional, kreativitas, bahasa dan komunikasi yang khusus yang sesuai dengan tahapan yang sedang dilalui oleh anak tersebut.

Bermain merupakan aktivitas bersenang sambil belajar yang terjalin secara alamiah. Anak tidak merasa terpaksa buat bermain, namun mereka hendak mendapatkan kesenangan, kenikmatan, data, pengetahuan, imajinasi, serta motivasi bersosialisasi (Sukatin et.al., 2020). Anak-anak memiliki beberapa aspek perkembangan, salah satunya adalah aspek sosial-emosional. Meski sosial dan emosional adalah dua kata yang memiliki makna yang berbeda, tetapi sebenarnya aspek sosial emosional ini tidak dapat dipisahkan. Hal ini dikarenakan kedua aspek ini saling bersinggungan satu sama lain. Perkembangan sosial emosional ini bertujuan agar anak memiliki keprcayaan diri, kemampuan bersosialisasi, dan kemampuan mengendalikan emosi.

Dalam psikologi perkembangan, banyak dibahas mengenai bagaimana tahap perkembangan sosial anak, diantara tokoh yang memberi konstribusi dalam hal ini adalah teori perkembangan psikososial Erik H. Erikson. Erikson mengatakan bahwa istilah psikososial dalam kaitannya dalam perkembangan manusia berarti bahwa tahaptahap kehidupan seseorang dari lahir sampai mati dibentuk oleh pengaruh-pengaruh sosial yang berinteraksi dengan suatu organisme yang menjadikan seseorang matang secara fisik dan psikologis (Emiliza, 2019).

Studi peran orang tua sudah dibahas sangat luas. Dilihat dari fungsinya keluarga memiliki tugas dan fungsi perawatan, dukungan emosi dan materi, serta pemenuhan 
peranan tertentu. Keluarga merupakan bagian penting dari unit masyarakat. Keluarga memiliki peran penting dalam merawat, mendidik, melindungi dan mengasuh anak. Menurut Anggraini et.al. (2020) mengembangkan aspek sosial anak perlu peran khusus keluarga untuk membentuk agar secara sosial anak dapat berkembang dengan baik. Keluarga dalam hal ini merupakan satuan terkecil sebagai inti dari suatu sistem sosial yang ada dimasyarakat.

Dalam hal ini, seorang ibu memiliki peran yang sangat penting dan utama dalam memberikan pembinaan dan bimbingan bagi anak baik begitu juga dalam perkembangan sosial anak. Banyak orang yang cerdas secara intelektual dan akademik namun mengalami kesulitan dalam berkomunikasi dengan lingkungan atau sosial yang kurang sehingga hal ini akan menghambat interaksi dengan orang lain.

Penelitian ini bertujuan untuk mengetahui bagaimana strategi orang tua terhadap perkembangan sosial-emosional anak usia dini selama masa pandemi. Serta penelitian ini akan lebih fokus menjelaskan tentang perkembangan emosional dan sosial pada anal usia dini.

\section{METODE}

Metode yang digunakan adalah metode penelitian kualitatif dengan pendekatan fenomenologis deskriptif (Kahija, 2017). Penelitian dilakukan di RA. ALIF. Teknik pengumpulan data yang dilakukan peneliti diantaranya adalah wawancara terstruktur dengan tujuan ingin mengetahui strategi yang digunakan oleh orang tua dalam perkembangan aspek sosial-emosional melalui instrumen yang telah disediakan oleh peneliti sebelumnya. Informan penelitian ini adalah orang tua yang memiliki anak usia dini 0-6 tahun yang berjumlah tiga orang. Penelitian ini menggunakan teknik triangulasi dalam pemeriksaan keabsahan data. Teknik triangulasi, yaitu teknik penyilangan informasi yang diperoleh dari sumber sehingga. Informan yang pertama adalah seorang ibu rumah tangga dari satu anak yang masih berusia 3 tahun. Sementara informan kedua merupakan seorang Guru SD single parent dengan satu anak yang masih berusia 4 tahun. Dan informan terakhir adalah seorang karyawan di perusahaan bank swasta dengan dua anak berusia 2 dan 5 tahun. Adapun analisa data yang digunakan adalah analisis data interaktif melalui beberapa tahapan yaitu tahap reduksi data, tahap penyajian data, tahap penarikan kesimpulan dan verifikasi data.

Penelitian ini menggunakan teknik triangulasi dalam pemeriksaan keabsahan data. Teknik triangulasi, yaitu teknik penyilangan informasi yang diperoleh dari sumber sehingga pada akhirnya hanya data yang absah saja yang digunakan untuk mencapai hasil penelitian. Teknik triangulasi (triangulasi metode), yaitu dengan mengecek ulang informasi hasil wawancara (Azizah et.al, 2020).

\section{HASIL}

Strategi orang tua terhadap perkembangan sosial emosi yaitu dengan memberikan pemahaman akan situasi pandemi. Selain itu adalah dengan mengadakan kegiatan lain yang dapat dilakukan dirumah termasuk bermain bersama sang ibu. Ditengah kesibukan para ibu, mereka berusaha untuk bisa mendidik dalam perkembangan sosial-emosional anak, khususnya ibu akan sangat mempermudah untuk memahamkan kondisi kegiatan yang berubah diakibatkan pandemi saat ini memahami dan membantu anak-anak untuk memahami perasaan sendiri dan perasaan anak-anak 
lain untuk mengembangkan rasa hormat dan kepedulian kepada orang lain. Selain itu strateginya yaitu dengan memberikan permainan edukatif (misalnya menyusun bangun ruang, tebak aku, dan lain sebagainya), memberikan tugas merapikan mainannya sendiri, bercerita dan mendongeng, dan lain sebagainya.

Berdasarkan hasil penelitian menyatakan beberapa kelompok emosional yang terdapat pada anak, yakni:.

\section{Kerumunan (crowd)}

Kerumunan akan berdampak karena kita hidup dalam dunia yang kompleks. Seseorang akan senang jika ada orang lain bermain atau berbicara dengannya. Berdasarkan hasil penelitian terdapat kerumunan (crowd) berdampak positif dan berdampak negatif pada anak usia 5 tahun. Berikut tabel dampak positif dan dampak negatif kerumunan pada anak 5 tahun.

Tabel 1. Dampak positif dan dampak negatif kerumunan (crowd)

\begin{tabular}{cll}
\hline No & \multicolumn{1}{c}{ Dampak Positif } & \multicolumn{1}{c}{ Dampak Negatif } \\
\hline 1 & Anak bisa menjadi periang & Anak menjadi setres \\
2 & Anak dapat melihat suasana berbeda & Ia menjadi bingung \\
3 & Anak dapat lebih interaktif lagi & Menjadi ketakutan \\
\hline
\end{tabular}

Dari hasil penelitian ini diketahui bahwa terdapat dampak positif dan negatif dari adanya kerumunan (crown) pada sosial emosional anak usia dini. Ketika dampak positif dalam kerumunan anak menjadi periang, dapat suasana baru. Hal ini terlihat dari terjadi interaksi yang baik. Namun, dampak negatif dari kerumunan yaitu anak menjadi stres, bingung, ketakutan disebabkan karena banyak anak-anak yang kurang dapat bisa bersosialisasi pada masyarakat luas dan membuat emosi seorang anak menjadi tidak dapat terkontrol.

\section{Komunikasi (Communication)}

Komunikasi adalah hal yang sangat diperlukan dalam kehidupan sehari-hari, baik anak-anak maupun orang dewasa. Serta membutuhkan komunikasi untuk menyampaikan apa yang anak inginkan. Komunikasi yang terjadi harus seimbang, jika tidak maka akan terjadi miskomunikasi antara pelaku. Berikut hasil penelitian dampak positif dan negatif komunikasi dari penelitian ini (Tabel 2).

Tabel 2. Dampak positif dan dampak negatif komunikasi

No Dampak Positif Dampak Negatif

\begin{tabular}{lll}
\hline 1 & $\begin{array}{l}\text { Ketika } \\
\text { mendapatkan anak-anak } \\
\text { dengan seseorang, dia bisa } \\
\text { belajar. }\end{array}$ & $\begin{array}{l}\text { Anak-anak kalau tidak seusia, jika ada } \\
\text { yang mengajarkan kata-kata negatif anak } \\
\text { ini dapat menyerap dengan cepat. }\end{array}$ \\
& $\begin{array}{l}\text { Ia dapat lancar berbicara } \\
\text { Ia akan lebih sering mengulang-ulang } \\
\text { perkataan negatif yang ia dapat. }\end{array}$ \\
& $\begin{array}{l}\text { Mendapatkan kosa kata baru, } \\
\text { dari dunia yang ia hadapi } \\
\text { selama ini. }\end{array}$ \\
\hline
\end{tabular}


Berdasarkan hasil penelitian pada tabel diatas dapat disimpulkan bahwa, perkembangan sosial emosional anak memiliki dampak positif dan negatif dari anak berkomunikasi. Dampak positif antara lain ketika anak senang melakukan kegiatan berkomunikasi, maka anak akan belajar berkomunikasi dengan orang lain. Selain itu, dampak positif lainnya anak dapat lancar berbicara, dan anak akan mendapatkan beberapa kosa kata baru, yang sebelumnya tidak diketahui. Hasil penelitian menyatakan dampak negatif komunikasi pada anak antara lain, ketika anak berbicara dengan tidak seusia dengannya, banyak kosakata yang didengar bermakna negatif, yang tentunya anak dapat menyerapnya dengan cepat. Serta anak akan lebih sering tentunya akan mengulang kata-kata yang didapatkan tersebut.

\section{Teknologi}

Teknologi merupakan salah satu dampak perkembangan zaman yang dapat di nikmati, namun teknologi dapat berdampak secara beriringan antara baik dan buruk, terlebih lagi kepada anak usia 5 tahun.

Tabel 3. Dampak positif dan dampak negatif teknologi

\begin{tabular}{|c|c|c|}
\hline No & Dampak Positif & Dampak Negatif \\
\hline 1 & $\begin{array}{l}\text { Dapat menambah } \\
\text { intelegensia }\end{array}$ & $\begin{array}{l}\text { Ketika didapatkan teknologi seperti televisi } \\
\text { sambil makan, mereka hanya bisa mendengar } \\
\text { jarang bisa menirukan kembali. Hal ini akan } \\
\text { menyebabkan speech delay pada anak. }\end{array}$ \\
\hline 2 & Pemahaman yang baru & $\begin{array}{l}\text { Kurang terkontrolnya apa yang dilihat anak-anak } \\
\text { ketika memainkan gadget. }\end{array}$ \\
\hline 3 & $\begin{array}{l}\text { Dapat beradaptasi } \\
\text { dengan teknologi yang } \\
\text { canggih diusia mereka } \\
\text { saat ini. }\end{array}$ & Mengurangnya daya ingat anak-anak. \\
\hline
\end{tabular}

Berdasarkan hasil penelitian pada tabel diatas disimpulkan bahwa teknologi seperti gawai, televisi, dan teknologi lainnya berdampak dampak positif dan negatif pada anak. Dampak positif dari teknologi antara lain menambah intelegensi anak, anak mendapatkan pemahaman yang baru, dan anak juga dapat beradaptasi dengan teknologi yang canggih di usia mereka saat ini. Sementara itu, dampak negatif teknologi pada anak antara lain televisi, anak akan lebih sering mendengar dan jarang menirukan kembali, sehingga anak bisa mengalami speech delay (keterlambatan berbicara). Selain itu juga ketika anak diberikan gawai dengan tidak ada pengawasan dari orang tua, akan membuat para orang tua tidak dapat mengetahui apa saja yang telah dilihat anak. Sehingga teknologi dapat menyebabkan berkurang daya ingat anak.

\section{PEMBAHASAN}

Sejak terjadinya pandemi Covid-19 di seluruh dunia termasuk Indonesia, menunjukkan bahwa peran orang tua atau keluarga dalam mengasuh, merawat dan juga mendidik anak sangatlah penting. Hal tersebut mengembalikan fungsi awal keluarga yaitu sebagai pusat segala kegiatan, tempat terjadinya pendidikan yang utama untuk anak. Keluarga merupakan lingkungan yang terdekat dengan anak-anak. sebagai 
anggota keluarga, orang tua memiliki peran yang besar dan bertanggung jawab atas pendidikan anak, sehingga bisa di katakan bahwa orang tua di dalam keluarga merupakan pendidikan yang utama dan pertama (Sofyan, 2019).

Pendidikan anak usia dini ialah sesuatu upaya yang diperuntukan kepada anak semenjak lahir hingga umur 6 tahun lewat pemberian rangsangan pendidikan supaya anak berkembang serta tumbuh dengan baik sehingga sanggup melakukan tiap tugastugas pertumbuhan cocok dengan tahap-tahap perkembangannya. Dari penjelasan diatas bisa diambil kesimpulan kalau pendidikan anak usia dini ialah orang yang lagi menempuh proses perkembangan serta pertumbuhan cocok dengan ciri nya masing masing sehingga pembelajarannya wajib memikirkan bermacam berbagai aspek supaya segala kecerdasan anak bisa tumbuh dengan maksimal (Syahrul \& Nurhafizah, 2021).

Anak usia dini adalah kelompok anak yang berada dalam proses pertumbuhan dan perkembangan yang bersifat unik, dalam arti memiliki pola pertumbuhan dan perkembangan (koordinasi motorik halus dan kasar), intelegensi (daya pikir, daya cipta, kecerdasan emosi, dan kecerdasan spiritual), sosial emosional (sikap dan perilaku serta agama), bahasa dan komunikasi yang khusus sesuai dengan tingkat pertumbuhan dan perkembangan anak (Kusumawati \& Zuchdi, 2019).

Kemampuan literasi atau kemampuan berkomunikasi pada anak akan mempengaruhi perkembangan sosial, emosi dan perkembangan kognitifnya. Jika anak mampu berkomunikasi dengan lingkungan sekitar maka akan tumbuh kepercayaan diri dan mampu bersosialisasi atau bisa diterima di lingkungannya. kemampuan berbahasa mempengaruhi penyesuaian sosial dan pribadi anak tentu akan mempengaruhi pula perkembangan emosi dan kognitifnya (Basyiroh, 2018).

Setiap anak yang dilahirkan tidak sama masing masing memiliki kelebihan serta kekurangannya, masing masing memiliki ciri yang berbeda. Anak usia dini merupakan masa manusia mempunyai keunikan yang butuh dicermati oleh orang berusia, anak usia dini unik dalam kemampuan yang dipunyai serta pelayanannya juga butuh serius supaya tiap kemampuan bisa jadi landasan dalam menapaki sesi pertumbuhan selanjutnya. Setiap anak merupakan makhluk individual, sehingga berbeda satu anak dengan yang yang lain.

Pada masa taman kanak-kanak (TK) merupakan masa kanak-kanak awal. Pola perilaku sosial yang terlihat pada masa kanakkanak awal, yaitu: kerjasama, persaingan, kemurahan hati, hasrat akan penerimaan sosial, simpati, empati, ketergantungan, sikap ramah, sikap tidak mementingkan diri sendiri, meniru, perilaku kelekatan. Menurut Erik Erikson (Mawar et.al, 2021) ada beberapa tahapan untuk mengindentifikasi perkembangan sosial anak: Tahap pertama, (percaya vs curiga) usia 0-2 tahun. Pada tahap ini anak akan merespon stimulus, anak akan mendapatkan pengalaman yang menyenangkan itu menumbuh rasa percaya diri, sebaliknya jika pengalaman tidak menyenangkan akan menimbulan rasa curiga; Tahap kedua, (mandiri dan ragu) usia 2-3 tahun. Dimana anak sudah bisa menguasai kegiatan meregang atau melepaskan otot-otot tubuhnya. Pada masa ini anak sudah mampu menguasai anggota tubuhnya dapat menimbulkan rasa otonomi, sebaliknya bila lingkungan tida memberi kepercayaan maka akan menimbulkan rasa malu dan ragu pada si anak; Tahap ketiga, (berinisiatif dan bersalah) usia 4-5 tahun. Masa ini anak akan menunjukkan sikap lepas dari orang tua dan anak akan bergerak bebas berinteraksi dengan lingkungannya. Situasi seperti ini akan menimbulkan rasa untuk berinisiatif, sebaliknya dapat menimbulkan rasa bersalah; Tahap keempat, (percaya diri dan rendah diri) usia 6 tahun-pubetas. Kondisi anak telah 
memasuki masa dewasa dimana perkembangannya untuk menyiapkan diri melaksanakan tugas-tugasnya. Anak akan mampu menguasai keterampilan tertetntu dan dapat menimbulkan rasa berhasil, sebaliknya akan menimbulkan rasa rendah diri pada anak.

Perkembangan sosial anak adalah kemampuan seorang anak dalam menyesuaikan diri dengan lingkungannya dengan di awali dari keluarga hingga orang yang belum pernah di kenalinya. Pertumbuhan sosial bertujuan agar seorang anak bisa bersosialisasi dengan orang sekitarnya dan membiasakan diri dengan area sosialnya. Orang tua menjadi tempat pertama kali seorang anak berinteraksi dan bersosialisasi, orang tua dan keluarga menjadi faktor penting dalam mengembangkan sosial anak usia dini. peran orang tua dalam mengembangkan sosial anak adalah mengejar keterampilan bahasa, mengenalkan lingkungan, menanamkan nilai budaya dan norma yang ada (Nandwijiwa \& Aulia, 2020).

Teori Erik Erikson tentang perkembangan manusia dikenal dengan teori perkembangan psiko-sosial. Teori perkembangan psikososial ini adalah salah satu teori kepribadian terbaik dalam psikologi. Seperti Sigmund Freud, Erikson percaya bahwa kepribadian berkembang dalam beberapa tingkatan. Salah satu elemen penting dari teori tingkatan psikososial Erikson adalah perkembangan persamaan ego. Persamaan ego adalah perasaan sadar yang kita kembangkan melalui interaksi sosial. Menurut Erikson, perkembangan ego selalu berubah berdasarkan pengalaman dan informasi baru yang kita dapatkan dalam berinteraksi dengan orang lain. Erikson juga percaya bahwa kemampuan memotivasi sikap dan perbuatan dapat membantu perkembangan menjadi positif, inilah alasan mengapa teori Erikson disebut sebagai teori perkembangan psikososial.

\section{SIMPULAN}

Orang tua diharapkan mempunyai pengetahuan dan kesadaran untuk menstimulasi segala aspek pertumbuhan dan perkembangan anak dengan baik. Berdasarkan wawancara yang telah dilakukan, disimpulkan bahwa strategi-strategi yang dilakukan antara lain memberikan pemahaman akan situasi pandemi, mengadakan kegiatan lain yang dapat dilakukan di rumah termasuk bermain bersama ibu, dan berusaha untuk bisa mendidik dalam perkembangan sosial-emosional anak. Dari hasil wawancara menyatakan bahwa komunikasi yang baik antar anak dan orang tua, khususnya ibu akan mempermudah untuk memahamkan kondisi kegiatan yang berubah diakibatkan pandemi saat ini.

Perkembangan sosial dan emosi yang positif memudahkan anak untuk bergaul dengan sesamanya dan belajar dengan lebih baik, juga dalam aktifitas lainnya di lingkungan sosial. Oleh karena itu, sangat penting memahami dan membantu anak-anak untuk memahami perasaan sendiri dan perasaan anak-anak lain untuk mengembangkan rasa hormat dan kepedulian kepada orang lain.

\section{REFERENSI}

Anggraini, V. A., Rahayu, E., \& Islam, S. N. (2020). Peran Orang Tua Dalam Pendampingan Anak Usia Sd/Mi Dalam Pembelajaran Online Di Saat Pandemi 
Covid-19. Auladuna: Jurnal Prodi Pendidikan Guru Madrasah Ibtidaiyah, 2(02), 92-105.

Azizah, L. S. N., Ispiyana, N., \& Nuryah, S. (2020). Strategi Orang Tua Dalam Menanamkan Pendidikan Karakter Anak Pada Masa Pandemi Covid-19. Journal of Multidisciplinary Studies, 4(2), 245-256.

Basyiroh, I. (2018). Program Pengembangan Kemampuan Literasi Anak Usia Dini. Jurnal Program Studi Pendidikan Guru PAUD STKIP Siliwangi Bandung, 3(2), $120-134$.

Cahyati, N., \& Kusumah, R. (2020). Peran Orang Tua Dalam Menerapkan Pembelajaran Di Rumah Saat Pandemi Covid 19. Jurnal Golden Age, 4(01), $152-159$.

Emiliza, T. (2019). Konsep psikososial menurut teori erikh. Erikson terhadap pendidikan anak usia dini dalam tinjauan pendidikan islam konsep psikososial menurut teori erik h. Erikson terhadap pendidikan anak usia dini dalam tinjauan pendidikan islam [PhD Thesis]. IAIN BENGKULU.

Iftitah, S. L., \& Anawaty, M. F. (2020). Peran Orang Tua Dalam Mendampingi Anak Di Rumah Selama Pandemi Covid-19. JCE (Journal of Childhood Education), 4(2), 71-81.

Kahija, Y. F. L. (2017). Penelitian Fenomenologis Jalan Memahami Pengalaman Hidup. Yogyakarta: PT Kanisius,

Kusumawati, I., \& Zuchdi, D. (2019). Pendidikan Moral Anak Usia Dini Melalui Pendekatan Konstruktivis. Academy of Education Journal, 10(01), 63-75.

Lilawati, A. (2020). Peran Orang Tua dalam Mendukung Kegiatan Pembelajaran di Rumah pada Masa Pandemi. Jurnal Obsesi: Jurnal Pendidikan Anak Usia Dini, 5(1), 549-558.

Mawar, M., Salamah, D. N., \& Fauziah, A. L. (2021). Sosialisasi Peranan Orang Tua Dalam Pembelajaran Daring Bagi Anak Usia Dini Di Masa Pandemi Covid 19. Prosiding Seminar Nasional Pengabdian Masyarakat LPPM UMJ, 1(1).

Nandwijiwa, V., \& Aulia, P. (2020). Studi Deskriptif Peran Orang Tua terhadap Perkembangan Sosial Anak Usia Dini pada Masa Pandemi Covid-19. Jurnal Pendidikan Tambusai, 4(3), 3145-3151.

Nurmalitasari, F. (2015). Perkembangan sosial emosi pada anak usia prasekolah. Buletin Psikologi, 23(2), 103-111.

Sofyan, I. (2019). Mindful Parenting: Strategi Membangun Pengasuhan Positif dalam Keluarga. JECCE (Journal of Early Childhood Care and Education), 1(2), 4147.

Sukatin, Q. Y. H., Alivia, A. A., \& Bella, R. (2020). Analisis Psikologi Perkembangan Sosial Emosional Anak Usia dini. Bunayya: Jurnal Pendidikan Anak, 6(2), 156171.

Syahrul, S., \& Nurhafizah, N. (2021). Analisis Pengaruh Pola Asuh Orang Tua Terhadap Perkembangan Sosial dan Emosional Anak Usia Dini Dimasa Pandemi Corona Virus 19. Jurnal Basicedu, 5(2), 683-696. 